\title{
POLICY IMPLEMENTATION OF THE LOCAL GOVERNMENT REGARDING THE PROHIBITION OF PROPERTY AND IMMORAL CONDUCT
}

\section{IMPLEMENTASI KEBIJAKAN PEMERINTAH DAERAH MENGENAI PELARANGAN PELACURAN DAN PERBUATAN ASUSILA*}

\author{
Budi Heryanto $^{1}$, Emaliawati ${ }^{2}$, Aji Mulyana ${ }^{3}$ \\ ${ }^{1}$ Sekolah Tinggi Hukum Pasundan Sukabumi, Jawa Barat Indonesia \\ Jl. Pasundan, Nyomplong, Kec. Warudoyong, Kota Sukabumi, Jawa Barat 43131 \\ e-mail: budiheryanto45@ gmail.com \\ ${ }^{2}$ Sekolah Tinggi Hukum Bandung, Jawa Barat Indonesia \\ Jl. Cihampelas No.8, Tamansari, Kec. Bandung Wetan, Kota Bandung, Jawa Barat 40116 \\ e-mail: emaliawati@gmail.com \\ ${ }^{3}$ Pascasarjana Program Magister Ilmu Hukum Universitas Suryakancana \\ Jl. Pasir Gede Raya, Kel. Bojongherang, Kec. Cianjur, Kab. Cianjur, Jawa barat Indonesia \\ e-mail: ajimulyana94@gmail.com
}

\begin{abstract}
Prostitution is an activity of offering sex edgaged to people to be enjoyed in general or voluntarily in order to obtain a reward for that person's sexual satisfaction. However, prostitution activity violates the norms and values of society as seen in prostitution activities in Sukabumi Regency area which often disturbs the community. Therefore the regional government issued Regional Regulation Number 5 of 2015 concerning the Prohibition of Prostitution and Immoral Acts which are the result of public policies which are forms or types of legal provisions that must be implemented in society, but at the level of implementation it is still not optimal. The purpose of this study was to find out how the implementation of the Regional Regulation of Sukabumi Regency in carrying out the rules prohibiting prostitution and immoral acts. The implementation of this local government policy has not regulated well because of many factors that affect its implementation, both from the regulation itself, human resources, inadequate facilities and infrastructure.
\end{abstract}

Keywords: Immoral; Policy; Regional Government; Prostitution.

\section{Abstrak}

Prostitusi merupakan kegiatan menawarkan tubuh seseorang kepada banyak orang untuk dinikmati secara umum atau secara sukarela, guna memperoleh imbalan atas kepuasan seksual orang tersebut, namun kegiatan tersebut melanggar norma dan nilai masyarakat, khususnya kegiatan prostitusi di daerah Kabupaten Sukabumi yang kerap meresahkan masyarakat, maka dari itu pemerintah daerah mengeluarkan Peraturan Daerah Nomor 5 Tahun 2015 tentang Larangan Pelacuran dan Perbuatan Amoral yang merupakan hasil dari kebijakan publik yang merupakan bentuk atau jenis ketentuan hukum harus dilaksanakan dalam masyarakat, namun dalam tataran pengimplementasiannya masih kurang maksimal. Tujuan dari penelitian ini adalah untuk mengetahui bagaimana implementasi Peraturan Daerah Kabupaten Sukabumi dalam menjalankan aturan larangan prostitusi dan perbuatan asusila. Pengimplementasian kebijakan pemerintah daerah ini belum berjalan dengan baik karena banyak faktor yang mempengaruhi proses pelaksanaannya, baik dari regulasi itu sendiri, sumber daya manusia, sarana dan prasarana.

Kata Kunci: Asusila; Kebijakan; Pemerintah Daerah; Prostitusi.

\footnotetext{
* Naskah diterima: 27 April 2021, direvisi: 8 September 2021, disetujui untuk terbit: 23 September 2021 Doi: $10.3376 /$ jch.v7i1.348
} 


\section{PENDAHULUAN}

Era zaman ini perubahan sosial mengalami perubahan yang signifikan. Salah satu faktor pendorong kemajuan pada saat ini, yaitu adanya perubahan pola hidup dan perkembangan teknologi di masyarakat. Pola perubahan tersebut membawa ke arah yang positif maupun negatif dalam kehidupan masyarakat. Oleh karena itu perubahan pola kehidupan dan teknologi ini tidak dapat dihindari oleh masyarakat, karena membawa pengaruh terhadap perubahan pola budaya, struktur, stratifikasi masyarakat, keyakinan masyarakat, pola dan gaya hidup (Cahyono, 2016).

Perubahan sosial tersebut tidak sedikit orang menghalalkan segala cara untuk memenuhi segala kebutuhan hidupnya baik itu dilakukan oleh perempuan ataupun laki-laki, salah satunya yaitu dengan menjual diri (menjadi pekerja seks komersial atau menjadi gigolo). Masalah tersebut merupakan persoalan, karena menyangkut pola kehidupan yang berlawanan dengan hukum yang berlaku. Sebab itu, masalahmasalah sosial tidak akan mungkin dapat ditelaah tanpa mempertimbangkan ukuran-ukuran masyarakat, mengenai apa yang dianggap baik dan apa dianggap buruk. Apalagi belakangan ini di zaman yang serba penuh kesulitan ekonomi. Keadaan ekonomi yang sulit menyebabkan orang-orang berani melakukan apapun untuk memenuhi kebutuhan hidupnya, beberapa di antaranya ingin menghasilkan uang banyak melalui jalan pintas tanpa pertimbangan akibat hukumnya. (Kartini
Kartono, 1992; Niko Prasetya, Tri Andrisman, 2018)

Pada dasarnya, pelacuran/ prostitusi menyangkut masalah sosial yang mengganggu nilai-nilai sosial dan moral. Pelacuran bertentangan dengan definisi sosiologi dari kejahatan (Sociological Definition of Crimes), karena dikategorikan sebagai perbuatan jahat yang bertentangan dan melanggar normanorma dalam kehidupan bermasyarakat karena tidak hanya dilarang oleh norma hukum dan norma agama saja, tetapi juga bertentangan dengan norma kesusilaan dalam setiap hati nurani manusia. (Islamia Ayu Anindia \& R.B Sularto, 2019)

Secara etimologis kata prostitusi berasal dari kata prostitutio yang memiliki artian menawarkan, menempatkan, dihadapkan. Pengertian lainnya yaitu menjajakan atau menjual, yang secara umum juga dapat diartikan secara sukarela memberikan tubuhnya untuk dinikmati banyak orang demi mendapatkan imbal jasa atas kepuasan seksual orang-orang tersebut.(I Komang Mahardika Wijaya \& I Gede Yusa, 2019)

Secara yuridis, peraturan perundangundangan khususnya Kitab UndangUndang Hukum Pidana (KUHP) tidak mengatur pelaku pelacuran dan penikmat jasa pelacuran yang diatur dalam Kitab Undang-undang Hukum Pidana hanya tentang pengelola rumah bordil atau germo dan penghubung/perantara atau makelar. Sebagaimana diatur dalam Pasal 296 KUHP, bahwa "Barang siapa dengan sengaja menyebabkan atau memudahkan perbuatan cabul oleh orang lain dengan orang lain, dan menjadikannya sebagai 
Budi Heryanto, Emaliawati, Aji Mulyana: Implementasi Kebijakan Pemerintah Daerah...

pencarian atau kebiasaan, diancam dengan pidana penjara paling lama satu tahun empat bulan atau pidana denda paling banyak lima belas ribu rupiah". Pasal 506 KUHP menyatakan bahwa "Barang siapa menarik keuntungan dari perbuatan cabul seorang wanita dan menjadikannya sebagai pencarian, diancam dengan pidana kurungan paling lama satu tahun".

Selain dari pasal-pasal tersebut, terdapat pula beberapa pasal lainnya dalam KUHP yang berkaitan dengan prostitusi, yaitu Pasal 297 yang mengatur tentang perdagangan perempuan dan anak laki-laki untuk dijadikan pekerja seks; dan Pasal 295 yang mengatur ketentuan yang mirip dengan Pasal 296 namun berbeda pada objeknya, yang mana pada Pasal 295 ini ditujukan kepada anak yang belum dewasa. (Pradana, 2015)

Pengaturan mengenai prostitusi ini juga termuat dalam peraturan yang dibuat oleh Pemerintah Daerah, diantaranya adalah Pemerintah Daerah Kabupaten Sukabumi sesuai dengan kewenangannya untuk mewujudkan ketentraman dan ketertiban, mengeluarkan sebuah kebijakan publik dalam bentuk produk hukum daerah yaitu Peraturan Daerah Nomor 5 Tahun 2015 Tentang Pelarangan Pelacuran Dan Perbuatan Asusila yang diundangkan pada tanggal 13 Mei 2015.

Menurut Bambang atas nama Kepala Satuan Polisi Pamong Praja Kabupaten Sukabumi Peraturan Daerah Nomor 5 Tahun 2015 Tentang Pelarangan Pelacuran dan Perbuatan Asusila, setelah diundangkan Perda ini dilakukan sosialisasi selama 2 (dua) tahun, dan baru diimplementasikan pada Tahun 2017 melalui kegiatan penertiban penyakit masyarakat, yang dilakukan di seluruh wilayah Kabupaten Sukabumi, khususnya di Kecamatan Palabuhanratu, Cikakak, Cisolok, Warungkiara, Cibadak, Parungkuda, Cicurug, Surade, dan Ciracap. Kegiatan ini dilakukan 1 (satu) Tahun sekali sejak Tahun 2017.

Merujuk pada ketentuan dalam peraturan perundang-undangan yang terkait dengan prostitusi di atas memberikan batasan tertentu tentang prostitusi. Sedangkan dalam Peraturan Daerah, kata prostitusi itu dengan jelas disebutkan, bahkan dalam judul peraturannya. Namun pengaturan yang ada juga ternyata belum mampu untuk dapat langsung dikenakan kepada pelaku prostitusi.

Pada Tahun 2017 terjaring 10 (sepuluh) orang, Tahun 2018 terjaring 13 (tiga belas) orang, dan 2019 terjaring 33 (tiga puluh tiga) orang, maka daripada itu orang-orang yang terjaring razia akan diserahkan ke kantor Satpol PP dan Panti Dinas Sosial untuk diberikan pembinaan dan diberikan pembekalan. Namun, dari data yang terjaring razia dari tahun 20172019 menunjukkan peningkatan yang signifikan pada kegiatan prostitusi ini.

Peraturan Daerah Kabupaten Sukabumi Nomor 5 Tahun 2015 Tentang Pelarangan Pelacuran dan Perbuatan Asusila merupakan hasil dari kebijakan publik, dan Peraturan Daerah tersebut merupakan salah satu bentuk atau jenis dari ketetapan hukum, dan harus diimplementasikan, serta untuk menilai berhasil atau tidaknya suatu Peraturan 
Daerah dalam penerapannya di dalam kehidupan masyarakat harus dilakukan evaluasi secara menyeluruh dari nilai proses penyusunan Peraturan Daerah, menelaah materi, dasar hukum dari pembuatan Perda tersebut dan efektivitas Perda tersebut dalam implementasinya di masyarakat. Selain itu, data tersebut dapat dijadikan sebuah gambaran bahwa pada akhirnya Implementasi Perda tersebut belum mampu memberikan jalan keluar atau solusi dalam mengimplementasikan peraturan tersebut.

Berdasarkan uraian diatas dapat diketahui bahwa Implementasi Kebijakan Peraturan Daerah Kabupaten Sukabumi Nomor 5 Tahun 2015 Tentang Pelarangan Pelacuran dan Perbuatan Asusila, sejalan dengan penelitian sebelumnya yang dilakukan oleh Hatta Abdi Muhammad dan Danang Noprianto dengan judul penelitian "Problematika Implementasi Peraturan Daerah Tentang Prostitusi Di Kecamatan Sungai Bahar Kabupaten Muaro Jambi”. Yang mana penelitian ini terkait dengan 3 (tiga) hal, yaitu: (i) adanya tujuan atau sasaran, (ii) adanya kegiatan, dan (iii) adanya hasil. Namun hal ini saja tidak cukup, karena implementasi merupakan proses dinamis dimana pelaksana kebijakan melakukan suatu kegiatan agar pada akhirnya memperoleh hasil yang sesuai dengan tujuan atau sasaran dari kebijakan itu sendiri. (Noprianto, 2019)

Dari perbedaan antara penelitian terdahulu dengan artikel ini adalah lokasi, informan, dan pihak-pihak yang terkait, namun ada kesamaan yang mana penerapan implementasi kebijakan tidak berjalan dengan baik.

\section{METODE PENELITIAN}

Metode penelitian yang digunakanan adalah pendekatan yuridis normatif, yakni penelitian untuk menemukan hukum bagi suatu perkara in concreto merupakan usaha untuk menemukan apakah hukumnya yang sesuai untuk diterapkan in concreto guna menyelesaikan suatu perkara tertentu (Rony Hanitijo Soemitro, 1990). Mengkaji dan mempelajari asasasas hukum peraturan perundangundangan dan kaidah-kaidah hukum positif juga, serta studi empiris dalam hal memperoleh data primer dengan cara wawancara kepada pihak-pihak terkait. Bahan dan data yang sudah terkumpul dianalisis secara kualitatif untuk mendapatkan hasil kesimpulan dan menjadi dasar penelitian Tinjauan Yuridis Normatif Peraturan Daerah Kabupaten Sukabumi Nomor 5 Tahun 2015 Tentang Pelarangan Pelacuran Dan Perbuatan Asusila.

\section{HASIL DAN PEMBAHASAN}

Implementasi Kebijakan Pemerintah Daerah Kabupaten Sukabumi Nomor 5 Tahun 2015 Tentang Pelarangan Pelacuran dan Perbuatan Asusila, dalam pelarangan dan penanggulangannya tidak hanya dapat diatasi dengan penegakan hukum pidana semata, melainkan harus dilakukan dengan upaya-upaya lain diluar hukum pidana (non penal). Upaya non penal tersebut melalui kebijakan politik, ekonomi, dan sosial budaya. Di samping itu upaya non penal juga dapat ditempuh 
Budi Heryanto, Emaliawati, Aji Mulyana: Implementasi Kebijakan Pemerintah Daerah...

dengan menyehatkan masyarakat lewat kebijakan sosial dan dengan menggali berbagai potensi yang ada di dalam masyarakat itu sendiri. (Niko Prasetya, Tri Andrisman, 2018)

Menurut Van Meter dan Van Horn membatasi Implementasi kebijakan sebagai tindakan-tindakan yang dilakukan oleh individu-individu (atau kelompokkelompok) pemerintah maupun swasta yang diarahkan untuk mencapai tujuantujuan yang telah ditetapkan dalam keputusan-keputusan kebijakan sebelumnya. Tindakan-tindakan ini mencakup usaha-usaha untuk mengubah keputusan-keputusan menjadi tindakantindakan operasional dalam kurun waktu tertentu maupun dalam rangka melanjutkan usaha-usaha untuk mencapai suatu perubahan besar dan kecil yang ditetapkan oleh keputusan-keputusan kebijakan. Yang perlu ditekankan di sini adalah bahwa tahap implementasi kebijakan tidak akan dimulai sebelum tujuan-tujuan dan sasaran-sasaran ditetapkan atau diidentifikasi oleh keputusan-keputusan kebijakan. Maka, dengan demikian tahap implementasi terjadi hanya setelah undang-undang ditetapkan dan dana disediakan untuk membiayai implementasi kebijakan tersebut (Budi Winarno, 2016; Hatta Abdi Muhammad \& Danang Noprianto, 2019).

$$
\text { Peraturan Daerah Kabupaten }
$$

Sukabumi Nomor 5 Tahun 2015 Tentang Pelarangan Pelacuran dan Perbuatan Asusila, yang diformulasikan oleh Pemerintah Kabupaten Sukabumi telah memberikan penjelasan mengenai tujuan pembentukan Perda prostitusi ini, Perda ini disusun sebagai pernyataan sikap masyarakat dan pemerintah daerah bahwa pelacuran dan perbuatan asusila merupakan perbuatan tercela yang perlu diberantas, dengan dasar hukum yang jelas dalam melakukan tindakan pemberantasan terhadap pelacuran dan perbuatan asusila dan melindungi masyarakat dari dampak negatif pelacuran dan perbuatan asusila.

Mencapai tujuan tersebut maka perlu adanya aturan atau hukum yang mengatur, sebagai pedoman pola hidup manusia yang memiliki peranan penting dalam mencapai tujuan ketentraman hidup bagi masyarakat (Alin, 2017). Maka daripada itu pemerintah Pemerintah mempunyai suatu kewajiban dalam melaksanakan Perda tersebut sebagaimana dalam Peraturan Daerah Nomor 5 Tahun 2015 Tentang Pelarangan Pelacuran dan Perbuatan Asusila Pasal 9, Kepala Daerah mempunyai kewajiban sebagai berikut:

(1) Bupati berkewajiban melakukan pelarangan dan perbuatan asusila

(2) Untuk kepentingan pelarangan pelacuran dan perbuatan asusila sebagaimana dimaksud pada ayat (1) Bupati berwenang:

a. Melakukan pencegahan dalam bentuk kegiatan promotif dan preventif di lingkungan pendidikan, serikat pekerja, organisasi kemasyarakatan dan komponen masyarakat lain;

b. Melakukan penindakan terhadap pelacuran dan perbuatan asusila;

c. Melakukan pembinaan dan rehabilitasi sosial terhadap germo, mucikari, pelacur, pelanggan pelacur dan pelaku perbuatan asusila; 
d. Melakukan penutupan lokalisasi pelacuran dan/atau tempat yang dipergunakan untuk pelacuran;

e. Melakukan pencabutan izin usaha, penutupan dan/atau pembongkaran hotel, panti pijat, salon, asrama, warung, kantor, tempat hiburan dan tempat-tempat usaha lainnya untuk kegiatan pelacuran dan asusila;

f. Melakukan kerjasama dengan Polri, Tentara Nasional Indonesia, Kejaksaan dan Pengadilan; dan

g. Melakukan kerjasama antar daerah dan/atau dengan pihak swasta, perguruan tinggi dan lembaga swadaya masyarakat.

Di dalam penerapan Perda ini, selain menjadi tugas Kepala Daerah/Bupati dibantu aparatur pemerintahannya, dalam hal ini peran serta masyarakat harus berperan dan berpartisipasi dalam penegakan Peraturan Daerah Kabupaten Sukabumi Nomor 5 Tahun 2015 Tentang Pelarangan Pelacuran dan Perbuatan Asusila, dalam Pasal 11 bahwa "masyarakat baik secara individu maupun secara kelompok dapat berperan serta dalam upaya pencegahan perbuatan pelacuran dan perbuatan asusila". Pada Pasal 12, peran serta masyarakat sebagaimana dimaksud dalam Pasal 11, diwujudkan dalam bentuk:

a. Memberikan informasi dan/atau melaporkan tentang terjadinya tindak pidana pelacuran dan/atau tindak pidana kesusilaan kepada Polri atau satuan kerja perangkat daerah yang tugas pokok dan fungsinya melakukan penegakan Peraturan Daerah;

b. Turut serta dalam mencegah terjadinya tindak pidana pelacuran dan tindak pidana kesusilaan; dan c. Bekerjasama dengan Pemerintah Daerah dalam pembinaan dan rehabilitasi sosial terhadap germo/mucikari, pelacur, dan pelanggan pelacuran dan perbuatan asusila".

Implementasi Perda prostitusi ini dapat dikatakan berhasil apabila kewajiban pemerintah daerah dan pihakpihak terkait dapat bersinergi dengan baik, dalam menjalankan tugas dan fungsinya masing-masing.

Salah satunya adalah kemampuan sumber daya manusia yang tersedia dan berkualitas (Said, 2018), sesuai dengan pekerjaan yang diisyaratkan oleh kebijakan yang telah ditetapkan, di samping itu ketersediaan sumber daya yang melaksanakan kebijakan juga harus terpenuhi. Apabila melihat dari segi geografis Kabupaten Sukabumi yang memiliki luas wilayah $4.128 \mathrm{~km}^{2}$ yang memiliki areal yang cukup luas yaitu 419.970 ha dan populasi jiwa sekitar \pm 2.436.729 pada tahun 2016, dimana mempunyai 47 kecamatan dan 386 kelurahan/desa, hal ini memerlukan personil aparat penegak hukum atau pun aparat pemerintahan yang cukup, akan tetapi karena keterbatasan APBD maupun APBN hal ini membuat kurangnya personil maupun aparatur pemerintah untuk penegakan peraturan daerah (PERDA). Dengan wilayah Kabupaten Sukabumi yang cukup luas itu, Kabupaten Sukabumi hanya mempunyai Polisi Pamong Praja sebanyak 161 personil, dimana jumlah tersebut hanya 101 yang sudah menjadi Pegawai Negeri Sipil (PNS) dan sisanya sebanyak 60 orang sebagai tenaga bantuan, juga terbatasnya 
Budi Heryanto, Emaliawati, Aji Mulyana: Implementasi Kebijakan Pemerintah Daerah...

biaya operasional yang dikeluarkan oleh pemerintah karena keterbatasan APBD. Hal ini cukup menyulitkan Pemerintah Daerah Kabupaten Sukabumi untuk melaksanakan penegakan Perda Nomor 5 Tahun 2015 Tentang Pelarangan Pelacuran dan Perbuatan Asusila di Kabupaten Sukabumi sebagaimana yang diharapkan oleh masyarakat maupun pemerintah dan tercapainya tujuan dan terlaksananya Perda tersebut.

Pelaksanaan operasi (gabungan) penegakan Perda di kabupaten Sukabumi yang dilakukan bersama-sama oleh aparatur pemerintah yaitu Satuan Polisi Pamong Praja (Satpol PP), Dinas Sosial, Dinas lainnya, TNI dan Polri di dalam pelaksanaan operasi penegakan perda tersebut hasilnya kurang maksimal karena bocornya informasi kepada lokasi atau tempat-tempat yang akan dilaksanakan operasi penegakan Perda tersebut, begitupun halnya di dalam pelaksanaan patroli rutin, petugas Satuan Polisi Pamong Praja (Satpol PP) Kabupaten Sukabumi sering menemukan pelaku maupun tempat-tempat yang digunakan sebagai tempat pelacuran dan perbuatan asusila tersebut dibekingi oleh oknum preman, lembaga swadaya masyarakat (LSM), maupun oknum aparat pemerintah sipil maupun militer, hal tersebut menyulitkan petugas dan menjadi permasalahan baru di dalam penegakan Perda tersebut.

Pelaksanaan operasi (gabungan) maupun patroli sering menangkap pelaku pelacuran dan para pelaku tersebut adalah para pemain lama yang sering melakukan atau menjajakan diri di wilayah
Kabupaten Sukabumi dan dengan alasan yang sama dilontarkan para pelaku tersebut ketika tertangkap oleh petugas yaitu alasan faktor ekonomi, karena tidak mempunyai pekerjaan lain, karena untuk menghidupi anak dan keluarga, mereka mengaku sebagai single parent dan dan mantan suaminya tidak bertanggung jawab terhadap anak-anaknya. Hal ini membuat kita miris karena mereka sering tertangkap walaupun sudah direhabilitasi oleh pemerintah dan diberi keahlian lain tetap saja tidak membuat mereka jera dan sadar, tetapi mereka tetap saja melakukan pekerjaan sebagai wanita penghibur.

Alasan keterbatasan ekonomi banyak pemain-pemain baru (Pekerja Seks Komersial) yang datang dan menjajakan diri sebagai Pekerja Seks Komersial baru di Kabupaten Sukabumi dan usianya masih relatif di bawah umur, perempuanperempuan tersebut ada yang dari daerah Kabupaten Sukabumi dan ada juga yang datang dari daerah tetangga Kota/Kabupaten yang lain, hal ini membuat Pemerintah Daerah Kabupaten Sukabumi harus lebih mengintefsikan dalam melakukan pencegahan, penindakan, maupun pembinaan dan halhal yang lain supaya tercapainya tujuan dari Perda Kabupaten Nomor 5 Tahun 2015 tentang Pelarangan Pelacuran dan Perbuatan Asusila.

\section{PENUTUP}

Pemerintah Kabupaten Sukabumi sesuai dengan kewenangannya untuk mewujudkan ketentraman dan ketertiban khususnya di daerah Kabupaten Sukabumi, telah mengeluarkan sebuah 
kebijakan publik dalam bentuk produk hukum daerah yaitu mengenai Implementasi Kebijakan Peraturan Daerah mengenai Pelarangan Pelacuran Dan Perbuatan Asusila di Kabupaten Sukabumi merupakan salah satu bentuk atau jenis dari ketetapan hukum yang harus diimplementasikan. Namun dalam pengimplementasian tersebut gagal karena tidak sinkronnya antara realita masyarakat dengan kebijakan yang berlaku, maka kerap terjadi berbenturan antara aturan itu sendiri dengan kebutuhan masyarakat, maka daripada itu tingkat keberhasilan dalam implementasi kebijakan di atas sangat tergantung dari kemampuan sumber daya yang tersedia (berkualitas), dalam proses implementasi melaksanakan kebijakan.

Mendorong semua pihak khususnya Pemerintah Daerah Kabupaten Sukabumi dan Pemerintah Pusat untuk lebih memperhatikan keberadaan penyakit masyarakat khususnya pelacuran di Kabupaten Sukabumi dalam melaksanakan penegakan aturan dan pendekatan secara manusiawi, diperlukan pengendalian sosial yang baik secara sosiologis maupun secara yuridis, agar dampak dari pelacuran tidak semakin merugikan kehidupan masyarakat.

\section{DAFTAR PUSTAKA}

Alin, F. (2017). Sistem Pidana Dan Pemidanaan Di Dalam Pembaharuan Hukum Pidana Indonesia. JCH (Jurnal Cendekia Hukum), 3(1), 14. https://doi.org/10.33760/jch.v3i1.6
Budi Winarno. (2016). Kebijakan publik era globalisasi. CAPS (Center of Academic Publishing Service).

Cahyono, A. S. (2016). Pengaruh Media Sosial Terhadap Perubahan Sosial Masyarakat Di Indonesia. Jurnal Publiciana, 9(1), 140-157. http://jurnal-

unita.org/index.php/publiciana/articl e/view/79

Hatta Abdi Muhammad \& Danang Noprianto. (2019). Problematika Implementasi Peraturan Daerah Tentang Prostitusi di Kecamatan Sungai Bahar Kabupaten Muaro Jambi. Jurnal Ilmu Sosial Ilmu Politik, 3(1), 18-28.

I Komang Mahardika Wijaya \& I Gede Yusa. (2019). Kriminalisasi Terhadap Perbuatan Penggunaan Jasa Prostitusi Di Indonesia. EJurnal Ilmu Hukum Kertha Wicara, 9(1), 1-17.

Islamia Ayu Anindia \& R.B Sularto. (2019). Kebijakan Hukum Pidana Dalam Upaya Penanggulangan Prostitusi Sebagai Pembaharuan Hukum Pidana. Jurnal Pembangunan Hukum Indonesia, 1(1), 18-30. https://doi.org/10.14710/jphi.v1i1.1 8-30

Kartini Kartono. (1992). Patologi Sosial. Rajawali Pers.

Niko Prasetya, Tri Andrisman, B. R. H. (2018). Implementasi Peraturan Daerah Kabupaten Lampung Selatan Nomor 4 Tahun 2004 Tentang Larangan Perbuatan Prostitusi Serta Pencegahan Perbuatan MAKSIAT (Studi Kasus 
Budi Heryanto, Emaliawati, Aji Mulyana: Implementasi Kebijakan Pemerintah Daerah...

di Wilayah Kabupaten Lampung Selatan). Poenale: Jurnal Bagian Hukum Pidana, 6(3), 1-12.

Noprianto, H. A. M. \& D. (2019). Problematika Implementasi Peraturan Daerah Tentang Prostitusi Di Kecamatan Sungai Bahar Kabupaten Muaro Jambi. Jurnal Ilmu Sosial Dan Ilmu Politik Fisipol Universitas Jambi, 3(1), 18-28.

Pradana, A. M. (2015). Tinjauan Hukum Pidana Terhadap Prostitusi Dan Pertanggungjawaban Pidana Para Pihak Yang Terlibat Dalam Prostitusi. Jurnal Hukum \& Pembangunan, 276. https://doi.org/10.21143/jhp.vol45.n 02.5

Rony Hanitijo Soemitro. (1990). Metodologi Penelitian Hukun Dan Jurimetri. Ghalia Indonesia.

Said, M. F. (2018). Perlindungan Hukum Terhadap Anak Dalam Perspektif Hak Asasi Manusia. JCH (Jurnal Cendekia Hukum), 4(1), 141. https://doi.org/10.33760/jch.v4i1.97 